\title{
THE AETIOLOGY OF RICKETS, EARLY AND LATE
}

\author{
By H. S. HUTCHISON, ASSISTED BY S. J. SHAH \\ (From the Civil Hospital, Nasik, Bombay Presidency)
}

\author{
With Plates 6 and 7 \\ PART I. \\ Preliminary Statement.
}

THe investigations which have resulted in the writing of this paper came to be made in the following circumstances. On my being posted to the Nasik district of the Bombay Presidency in September, 1920, I began inquiries into the dietary of the poorer classes of the community, the earliest of which was conducted among the constables at the Police Head-quarters and the labourers at the Acetone Factory, and was directed towards the question of the sufficiency of their pay. The results of this inquiry showed that these two classes of men and their families were living on a dietary consisting of an excess of carbohydrate, and very deficient in animal fat and vegetables, and that anaemia and a scorbutic condition were commonly found among them.

The investigation was then extended to the families of the comparatively well-to-do, clerks and others on a monthly pay of Rs. 50 and upwards, who were found to consume a much larger amount of milk and ghee (clarified butter), and whose diet in consequence showed no such fat deficiency as was found among constables and labourers. The omission of milk and ghee from the dietary of the lower classes was admittedly due to the, for them, prohibitive cost of these articles.

While these inquiries were going on, about 2,000 children of all ages up to 12 were examined in Nasik and in the various towns in the district. The majority of these children were the sons and daughters of agriculturists, artisans, and labourers. The results showed that, though most of these children appeared to have a scorbutic taint, very few showed signs of rickets, and in none of the infants was active rickets found. It therefore appeared to be true that rickets was a rare disease in the district: and the first conclusions come to were that the diet of the poorer classes, as a whole, contained an excess of carbohydrate (taken in the form of bajri, a millet) and a deficiency of vegetables and fats, 
particularly animal fats; and that these errors in diet accounted for the conditions found.

But meanwhile a few cases of late rickets were brought to the Civil Hospital for treatment, and, as the numbers of such cases and of early rickets began to work up as a result of cures obtained, it became more and more evident that, far from being a rare disease, rickets was a very common complaint in Nasik city ; and that its existence had been cloaked, and so had escaped detection, by the fact that it occurred in one class alone, the well-to-do Hindu and Mahomedan families, and that late rickets had not been recognized by the local medical practitioners as rickets, but had been treated as a form of malaria, or rheumatism, under the name of 'haddi tap' or bone fever.

Now at the present time the aetiology of rickets is being discussed from two points of view. The first opinion (Mellanby and Hopkins) is that it is a deficiency disease due to lack of the anti-rachitic vitamin in the dietary, though the holders of this opinion also admit that other factors, such as an excess of carbohydrates, a deficiency of protein, and a want of fresh air and exercise, are supplementary causes.

The contrary opinion (Findlay) is that a lack of fresh air and exercise is the most potent cause of the disease.

It is a commonplace remark in India that the poor live on the verge of famine; and, if the generalization is a true one, this deficient dietary should render the children liable to rickets. But there are other sharp contrasts between the conditions of life among the poor and those to be found in the cases of the well-to-do, and the most prominent of these is the mode of lifeespecially of the women of the two classes. It has been an immemorial Indian opinion that women should, as far as possible, live a life of seclusion, and modesty is the most prized of virtues in that sex. But, among the poor, seclusion is impracticable, for a wife's help is needed not only in the fields but also with the artisans.

The purdah system has therefore been confined to the upper classes, and is regarded as a mark of social position. A Mahomedan woman, who has not practised it, often goes into purdah as soon as her husband's means will allow of it; all the well-known Mahratta families, such as the Bhonslas of Shivaji's house, have their women 'gosha'; and the members of the theocracy, the Brahmins, though they repudiate the charge that their women observe 'purdah', all readily admit that they are kept secluded by custom, if not by religion.

In this paper, then, I propose first of all to describe at length the habits and customs of the different classes, and follow this with a discussion of results obtained from the diet inquiry. In the second part of the paper, I will consider rickets from the clinical aspect and discuss the aetiology of the same from results obtained; and, lastly, I will mention some points regarding the clinical features and aetiology of late rickets. 


\section{Social and Economic Conditions in the Town of Nasik.}

The Nasik district covers an area of 8,140 square miles, and is situated at the top of the Western Ghats about 100 miles from Bombay. The district embraces country of very variable character, that to the north and west being hilly and malarious with a heavy rainfall, while to the east it merges into the Deccan plain with a much lighter rainfall and a more salubrious climate. The hilly tracts are inhabited by aboriginal tribes, Bhils, Kolis, and Konkanis, while Mahrattas and other classes of Hindus occupy the plains. The Brahmins and other high-caste Hindus are usually found in the larger towns. Mahomedans are not very numerous.

In Nasik itself the population is sharply divided into two strata :

1. The upper stratum-locally known as the pandarpeshas, or wearers of white clothes-includes pleaders (lawyers), priests, merchants, shopkeepers, and Government clerks. This class would correspond to the upper middle class in England. These families often own the houses which they occupy, and their incomes range from Rs. 50 per mensem upwards. The majority of this elass, i. e. practically all the pleaders, priests, and Government clerks, are Brahmins. Nasik is a sacred city and a point of pilgrimage, and on this account the local Brahmins are rigidly orthodox, much more so than in other and non-sacred towns of India. This class also includes the other high-caste Hindus, who trade and keep shops, and well-to-do Mahomedans who are chiefly merchants, contractors, and tradesmen.

2. The lower stratum is composed of artisans, agriculturists, and labourers. It includes the lower Hindu castes, the pooror Mahomedans, and the large class of untouchable Hindus or depressed outcastes-Mahars, sweepers, \&c.

It is rather difficult for one used to Western customs to realize how sharply these two classes are differentiated from one another. There is no question of social intercourse between the two, and marriage is strietly confined to caste. In many ways, however, the classes resemble one another, and similar factors operate in both. Their general conditions of life are the same as regards climate, sanitation, early marriage, incidence of malaria, clothing, and so on. It may indeed be said that the two classes resemble each other in every way except two-habits of life and diet-and in these we have an exceedingly sharp contrast.

The extensive inquiry by Miss Ferguson into the social and economic conditions in Glasgow in 1917 (1) brought out clearly the close relationship between fresh air and rickets. The difficulty, however, in her inquiry was the fact that rickets was not found to any appreciable extent in the well-to-do classes, rickets being associated with poverty and overcrowding, i. e. with poor diet and lack of fresh air and exercise. It followed from this that those factors which are at present considered to produce rickets-diet and lack of fresh air-were both found in the same class, and hence, in order to determine which of the two was the causal factor, it became necessary to compare families in the same social class, i. e. those 
families that were rachitic with those that were not; and it would therefore hardly be expected that any great difference in diet would be found. The well-to-do classes were necessarily left completely out of the inquiry, and so a valuable control was lost.

In the present inquiry, we find a very different state of affairs. Rickets in Nasik is far more prevalent among the well-to-do, and hence, instead of comparing different sections of the same class with one another, we can compare one complete class with the other, and since one is well-to-do and the other poor, we at once meet with certain strong contrasts as regards food and mode of life, but not in the way that we would expect. We find that while the well-to-do eat the best food, in this class the lack of fresh air and exercise is most marked, while the reverse occurs in the poorer; hence, we have our factors arranged in an extremely suitable manner for the purpose of study. In Glasgow, both the factors were found in the poorer class and neither in the well-to-do; in Nasik one class possesses factor $A$, but not B, while the other class has factor $B$, but not $A$.

\section{Habits of Life.}

The individuals of Class 1, for occupational reasons, generally lead a sedentary life. They seldom play games and rarely go for walks. At the same time, they are much more rigidly bound by customs, partly religious and partly social, and these customs are more carefully observed in Nasik than in many other places. These customs cannot be defied without incurring social and, in many cases, religious ostracism, i. e. being outcasted. Here, again, it is difficult for one who has not resided in India to realize the significance of these facts. The customs are particularly binding on the women, and there is little doubt that their strict observance is due almost entirely to the prejudices of the women themselves, who are thus subjected to conditions of life which would never be tolerated in England.

Mahomedan women of Class 1 are all strictly purdah, and even when they travel in a carriage or cart, have to be screened from public view. They practically never leave the house except to visit relatives, and, as a result of this, children are seldom taken out. In any case, a newly-born child is not usually taken out for at least three or four months, and this period is very considerably prolonged if by any chance the child is suffering from a slight cold, malnutrition, or other complaint. Even if the children are healthy, the very nature of the mother's existence prevents their being taken regularly. When they can walk and otherwise look after themselves, they run about like ordinary children. About the age of 12 , girls again go into purdah, and from that day till their death they seldom leave the house.

The high-caste Hindu women are not technically purdah. They may go out when they like, but they have to devote a great part of their time to cooking and housekeeping. There is also a tradition of extreme modesty amongst them, and for these reasons a high-caste Hindu woman seldom leaves her house for more 
than half an hour daily. They do all the cooking and housework and only go out to attend marriages, to go to the temple, or to perform religious ablutions at the river. The last object is now rarely carried out, as most houses have water laid on from the sacred Godaveri. The women occasionally go on pilgrimages. The following are striking instances of the 'semi-purdah' found in this class :

(a) On her husband's death, the widow's head is shaved; she is restricted to wearing one garment only, and to one meal a day ; she must not leave her husband's house for a year.

(b) A newly-confined woman must not leave her room for three months. During the first month at least the room is carefully closed up so that the woman and child may not catch cold, and during this period she is unclean. On May 28 (the hot season of the year), I saw a Brahmin woman who had been confined six weeks previously. She was in the corner of an inner room, and was surrounded by curtains so that every ray of light was excluded and the entrance of fresh air prevented as far as possible. There was a charcoal brazier burning in this confined space. When the curtain was drawn back, it was with the greatest difficulty that I could see the woman; yet she had lived in this condition for six weeks. This is only an instance of what is almost universal among women of the better classes, but no power of imagination can picture the horror of the scene. The child is, of course, kept with the mother, and so it does not see the light for the first two or three months of its existence.

(c) A newly-born child is not taken out of the house as a rule for the first six months of its life. The date of its first walk abroad is delayed till an auspicious day arrives, and in some cases which I have seen this has been when the child was a year old. In several other cases, where the child was supposed to be delicate, this period has been prolonged up to eighteen months and even two years. Even after the child is taken out, it does not get a daily outing; it js taken out only occasionally.

(d) A woman must not frequent public places where men are to be met.

Infant marriage prevails, and on reaching the age of 12 a girl who has been attending school is sent to her husband's house, where she does all the cooking and housework under the mother-in-law's directions. In other words, she enters the semi-purdah of the Hindu married woman.

At this point I desire to emphasize the fact that in this stratum of society in Nasik (and I include both Hindu and Mahomedan) there are two periods in the woman's life when she is exposed to the purdah factor-in infancy and after about the age of 12. In the case of men, there is but one period, and that is in infancy. The relationship of early and late rickets to these periods will be shown later.

\section{Housing.}

Many of the houses of the well-to-do are ancestral, and they are often large and well built, though not in the same sense as this is understood in England. They are of a different design, the leading idea being privacy for the women. 
Since the houses are more crowded together than in England, this privacy can only be obtained by cutting down the window space of those rooms most occupied by the women.

Mahomedans emphasize this idea of privacy, and build as far as possible so that they cannot be overlooked. The windows are small and high up and the rooms are dark, especially the kitchen. The housing conditions of these women are extremely bad. This statement is borne out by Dr. (Miss) Greenfield of Poona, who says, "When I came to Poona, I was shocked to find Mahomedan women living with no yard or open roof, and purdah seemed more horrible than it had in the North' (2). In England there is no parallel to such conditions.

Hindu houses generally have a large reception room in front on the ground, or first, floor, and the rest of the house is taken up with numerous small rooms behind. The kitchen is among these, and the women and children spend most of their day in these small dark rooms. The darkness of these rooms is intensitied by the fact that the walls are discoloured with smoke, and while the women are working the children are laid in the corner of the room. In the older type of house in Nasik, the bad hygienic conditions must be seen to be appreciated. Such houses form the majority of those in Nasik. There is usually a small dark courtyard a few feet square with dark rooms leading off the surrounding verandah. The rooms are so dark that one can with difficulty see into them from the outside. The rooms in which the women and children spend most of their day are in both types of house very dark, and though a certain amount of fresh air gains admission, the rooms, never stuffy, are very warm for one unaccustomed to them. In the cold weather and rainy season, i. e. two-thirds of the year, the rooms are closed as much as possible. The streets in which the well-to-do reside are narrow, and it will be readily understood that very little light can gain admission to a house where the rooms open into a central, badly lighted courtyard.

In the past few months I have examined a very large number of such houses. The condition of affairs is worse than what one finds among the poorest classes at home. To home conditions, darkness is added, and the women do not go out to anything like the same extent that the poor people at home do.

Turning now to the other class-the lower castes composed of artisans, labourers, and agriculturists-we find a very different picture. The life led is of necessity more active, and more in the open. There are no rules as to purdah and no custom of semi-purdah for the women, who have to work as well as the men in the majority of cases, and especially among the agriculturists. Both men and women have a hard life, especially in years of scarcity. The women are obviously stronger and in better condition than those of the better class, among whom there is often a tendeney to stoutness. Owing to the outdoor life, the children cannot be left at home. While the mother is working, the child is placed on a shawl under a tree or in some improvised shelter, and is often given a small dose of opium to keep it quiet so that it shall not require any attention.

The houses occupied by these labourers are usually one-roomed ill-built huts 
with a hole in the roof for a chimney. Often they live in bamboo or matting shelters. Their mode of living is poor in the extreme, but their houses are the opposite of air-tight and they themselves are in the open all day long.

In the outlying parts of the district, where the aboriginal tribes are found, the mode of life is in striking contrast to that of Class 1 in Nasik. The people are very poor and seldom obtain regular meals. They are a bardy race, keen hunters, living in the open and capable of considerable feats of endurance. Their houses are mere hovels and their dietary is very poor. At Bandardhara, where a large dam is in course of construction, I had the opportunity of examining the mode of life of several types of Indian. Some came from local famine areas owing to failure of crops in part of the district, and others belonged to a criminal tribe. The conditions of life of all were of the poorest description. The large majority were living in the open or under matting shelters. Adults and children lived in the open all day long : their food was of the poorest kind, and hardly any animal food was consumed. Conditions similar to this prevail in many parts of the district, but they differ but little from those found among the lower castes in Nasik.

It is clear then that we have two classes diametrically opposed. In the better class in Nasik, the women and children live under much the same conditions as one finds among the poorer classes at home, while the poorer classes receive plenty of fresh air and exercise. Before taking up the question of diet among these classes, it would be advisable to consider some of the other factors which have been mentioned by Miss Ferguson in her inquiry previously mentioned.

The present inquiry has been greatly simplified, since in all classes breastfeeding is practically universal. In no case have I found artificial foods being used. Lactation is prolonged up to two years, though it is not uncommon to find it at three, or even four, years. Breast-feeding was usually supplemented with other food about the seventh or eighth month; in the well-to-do classes, cow's milk was always given; among the poorer classes, it was seldom used. Rice was usually employed. It is certain, therefore, that the well-to-do infant got better food and more fat-soluble vitamin than the poorer. This will be borne out when the dietaries of the two classes are considered, as it will be shown that the mothers of Class 1 eat much more of the fat-soluble vitamin-containing foods than do the mothers of Class 2 .

In the Glasgow inquiry, it was concluded that the health of the mother was probably merely an index of social conditions, and that at most it could only be regarded as a contributory factor in the development of rickets. This conclusion is borne out in the present inquiry. Brabmin women are as a rule well nourished, but phthisis and anaemia are rampant among them, and this is undoubtedly due to the semi-purdah system of living, so that the health of the mother is merely an index of social conditions. The women of the poorer classes, and the children also, are of much finer physique, and the explanation of this bas already been given. I can endorse entirely the statement of Noël Paton and 
Watson when they say that 'a point of considerable interest demonstrated in our observations is the more rapid growth of the pups kept in the open air' (3).

Miss Ferguson also concludes that the most striking difference between mothers of the rachitic and of the healthy children was one of personality, which expresses itself in the better care bestowed on the children in the non-rachitic families. In Nasik the child of the Brahmin woman is far better looked after than that of the poorer Hindu so far as cleanliness and tidiness are concerned. In Mahomedan families, on the other hand, the children are always very dirty and often suffer from skin diseases. Later on we shall see that rickets is most frequent among the Mahomedans and better-class Hindu, particularly the Brahmin, so that evidently the want of cleanliness and tidiness is not of prime importance in the causation of the disease. It is possible that the 'better care' mentioned by Miss Ferguson includes the taking out of the child, which no mother would omit to do if she had any idea of the necessary care to be bestowed on a child.

Owing to the fact that in Nasik I am comparing the well-to-do class with the poorer class, it is not necossary to deal with all the factors considered by Miss Ferguson in the Glasgow inquiry. Some of these, however, may be referred to briefly.

During the present inquiry, 100 families of the well-to-do and 124 of the poorer classes in Nasik were visited with a view to determining the prevalence of rickets in each. Factors such as early marriages, the influence of heredity, malaria, or venereal disease, sanitation or climate, need not be considered, as they are common to both classes. The following details with regard to stillbirths, miscarriages, and infant mortality are interesting :

1. Still-births and Miscarriages.

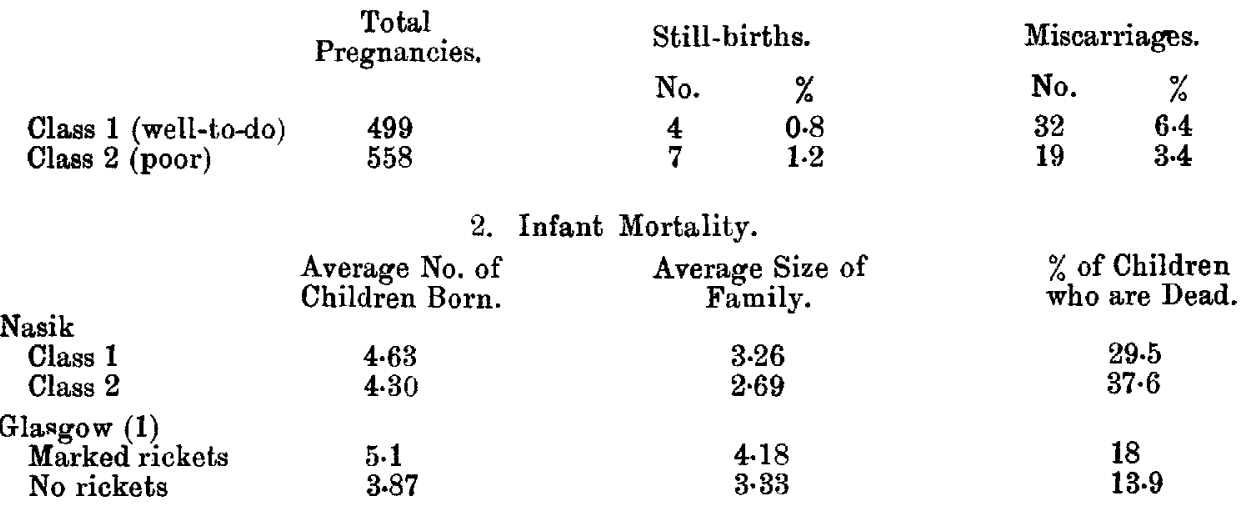

These figures will show the appalling mortality which exists among children in Nasik-a town corresponding to a county town at home. I have not got any evidence to show what this mortality is due to, but a mortality of nearly 30 per cent. among the well-to-do children, compared with 18 per cent. among the poorest families of Glasgow, is eloquent testimony to the unhygienic life in this class, and from what $I$ have seen $I$ am in no way surprised. It is 
clear, however, that the two classes are very similar as regards pregnancies, stillbirths, and miscarriages, and therefore these factors may be neglected so far as our present inquiry is concerned.

\section{A Study of the Dietary of Different Classes in the Town of Nasik.}

This was carried out on the lines of similar studies in Great Britain, and the method of investigation was that described in the Report upon the Study of the Diet of the Labouring Classes in the City of Glasgow by Miss Lindsay. It is not proposed to publish the results of the present inquiry in extenso, but the more salient points are given below.

In all, the dietaries were studied over 152 weekly periods and the families were divided into two groups: (1) Fitters and clerks. Their pay ranged from Rs. 45 to 250 per mensem. The women of this class lived a very secluded life, amounting to purdah. This class corresponds to the Class 1 described in the preceding part of this paper. (2) Labourers at the Government Acetone Factory and police constables on a pay of about Rs. 20 to 25. None of the women in these families kept purdah. The women had to work in order to increase the family earnings. This class does not represent the lowest-paid worker in the district, but it includes most of the Class 2 mentioned previously. They were chosen for the study because they were living together and could be easily controlled.

TABLE I. Showing the average Consumption of Food among the poorer and better-paid Classes in Nasik during the year 1920-1.

Class 1-better paid. Class 2-poorer paid.

$$
\text { Particulars. Class 1. Class } 2 .
$$

Number of families

Adult equivalent of families

Energy value of dietary in calories

Percentage of fat calories in total calories

Percentage of cereals in dietary

$43.9 \quad 75 \cdot 3$

Vegetables per adult per day in ounces

$4 \cdot 6$

$75 \cdot 3$
$2 \cdot 8$

Food per adult per day in grm.

1. Animal
(a) Protein
$27 \cdot 1$
$34 \cdot 4$
(c) Carbohydrate

2. Vegetable
(a) Protein
(b) Fat
(c) Carbohydrate
62.6
$25.1 \quad 41.3$
$489.0 \quad 687.0$
(a) Protein
(b) Fat
89.7
$59 \cdot 5$
$499 \cdot 0$
(c) Carbobydrate

3. Total

The Indian dietary does not show the endless variety of food-stuffs seen in European dietaries. Similar articles of diet were eaten by both classes, though 
the relative amounts of each varied, and accordingly it was possible to compare one class with another and to note the variations which occurred with increase in income. Moreover, such a comparison makes it possible to judge the effect on the dietary of an increase in the size of the family (other things being equal), and also to show what changes oceur as the days pass farther and farther from pay day.

The average results are shown in Table $I$, and with regard to these the following points may be noted: 1 . The caloric value of the dietary in Class 2 is higher than in Class 1. 2. The total fat consumed in Class 1 is greater, and this applies especially to animal fat. The percentage of energy from fat also rises. 3. The cereals consumed in Class 2 are much greater than in Class 1. 4. The vegetables in the diet are deficient in both classes, but particularly in Class 2.

It will be seen that there is a great difference between the two classes. There is a sudden rise in the consumption of animal food, and particularly animal fat. The increase in total fat is not proportionate to the increase in animal fat. The former increases from $44.3 \mathrm{grm}$. to $59.5 \mathrm{grm}$., while the latter increases from $3.0 \mathrm{grm}$. to 34.4 , an increase of $15.2 \mathrm{grm}$. compared with one of 31.4 . The fat increase, therefore, in passing from the lower-paid to the higher-paid worker is not merely a fat increase; it is an animal fat increase. This indicates a greatly increased consumption of milk and ghee, as is shown in the following:

$\begin{array}{ccc} & \text { Milk in oz. } & \text { Ghee in oz. } \\ \text { Class 1 } & 7.65 & 0.84 \\ \text { Class 2 } & 1.01 & 0.05\end{array}$

The consumption of fresh vegetables is deficient in both classes. There is a slightly higher consumption in Class $1-4.6$ ounces per adult per day compared with 2.8. While no standard exists for the amount of fresh vegetables necessary in the dietary of the Indian labourer, the quantity consumed is far below that consumed by the British worker, and is much less than the allowance of eight ounces of fresh vegetables per day to the conviet in Indian jails.

Generally speaking, it will be noticed that the Indian dietary includes more animal food with increase in income and that it approximates more to European standards. It has been shown by Breinl and Young (4) that the metabolism of natives of tropical countries is the same as that of natives of colder climates, and that in the former nature does not have recourse to a special metabolism to regulate body temperature. The energy requirements in each are the same, provided the basal metabolism is the same. In view of this and of the fact that an increase in income leads to an increased consumption of animal food and to a closer approximation to European standards, it would appear that the suitable dietary for the Indian is roughly the same as for the European. This does not imply that the same energy value is required in the Indian's dietary, for it is probable that his basal metabolism is less, but it does imply that the balance should be approximately the same. Apart from basal metabolism, the members of Class 1 lead sedentary lives, and hence their energy requirements are not so great as in Class 2 or as in the European. 
There are other facts to support this view. In this country pay is disbursed monthly, and the expenditure on animal food is greater at the beginning of the month than at the end. This, of course, applies to the lower paid only, and amongst them, just before pay-day, the energy value of the dietary may fall to 2,000 calories or less. Cheaper, i. e. more cereal, food is purchased as the days pass from pay-day, thus permitting of a larger number of calories being purchased per anna. From results obtained, shown in Table II, it will be seen that as the size of the family increases the quality of the dietary is adversely affected in that $(a)$ the amount spent on food per adult diminishes, $(b)$ the caloric value of the dietary diminishes, $(c)$ the percentage of energy from fat diminishes. Similar results are obtained if we take averages of the food consumed by families during the first, second, third, and fourth weeks after pay-day. Lastly, there is the work of McCay on the Bengal Jail Dietaries (5), which shows that if the high cereal dietary is eaten, it is not properly absorbed.

TABLE II. Showing the effect of the size of the Family among Labourers and Police Constables in Nasil on the Amount spent on and Quantity of Food consumed.

Adult equivalent of family

No. of families in group

1. Labourers.

Cost of food per adult per day in annas

Energy value of dietary per adult per day in 3781

$\begin{array}{rrrr}1.70 & 2.55 & 3.44 & 4.72^{*} \\ 13 & 24 & 19 & 16 \\ 4.24 & 4.27 & 3.54 & 3.20 \\ 3781 & 3968 & 3476 & 3196 \\ 891 & 929 & 981 & 998 \\ 12.0 & 10.7 & 9.8 & 9.8\end{array}$

Calories purchased per anna

Percentage of fat calories in total calories

$12 \cdot 0$

$10 \cdot 7$

9.8

$9 \cdot 8$

\section{Police Constables.}

Adult equivalent of family

No. of families in group

1.83

Cost of food per adult per day in annas

7

Energy value of dietary per adult per day in

5.52 calories

4574

Calories purchased per anna

Percentage of fat calories in total calories

828

$13 \cdot 2$

2.65
23
$4-25$
3919
923
12.0

$3 \cdot 33$

4.41

12

$\begin{array}{rr}3 \cdot 52 & 3 \cdot 36 \\ 3254 & 3483\end{array}$

* The figures shown in the last column include families over four adults. The families with an adult equivalent of over five are too small in number for an average to be taken, and therefore they have been included with those families whose equivalent is between four and five.

These facts, I consider; show that there is insufficient money to purchase the more expensive animal food, and this has been borne out by subsequent inquiries. I conclude from this that the dietary of the poorer classes is selected from necessity and not from choice. The lower-paid worker must purchase the cheapest form of food to satisfy his hunger, and therefore the high carbohydrate dietary is not due to racial and climatic causes but to economic. If this were not so, the dietaries between the two classes would not have been so widely divergent and nature would have arranged for the complete absorption of a high carbohydrate diet.

The chief articles of the dietary are bajri (millet), husked rice, wheat, pulses, and sweet oil. Animal food consists of milk, ghee (clarified butter), dry 
fish, and mutton. Mutton and dry fish are not eaten by Brahmins and certain other castes. The vegetables vary with the season of the year. There is little doubt that the dietary of Class 2 is deficient in fat-soluble vitamin and in antiscorbutic vitamin, if one can judge from the food consumed. In any case, the content in these substances is obviously far less than obtains in the case of Class 1. There are thousands of poor Indians in Nasik itself who never touch milk and ghee from the beginning of the month to the end, and whose dietary is over 90 per cent. cereal. It cannot be denied that such dietaries are very deficient in fat-soluble vitamin, while the dietaries of the better-paid workers are much better off in this respect.

When the dietaries of the above classes are considered more in detail, the striking differences between the two are more clearly shown. I am conscious of the fact that the number of families among the better paid are small, but my figures have been completely borne out by inquiries which I make from every patient who comes under my care and which $I$ have obtained in my house-tohouse visitation. An increase in the number of families would doubtless reduce the margin of error, but the differences are so distinct that the main form of the curves of distribution would be but little altered.

\section{The Energy Value of the Diet.}

The energy value of the dietary of Class 1 was on an average 2,970 calories as compared with 3,680 among the poorly paid. In the former 444 calories, or 15 per cent., were derived from animal food, while in the latter 64 calories, or 1.7 per cent., were so obtained. The distribution was as follows :

1. Total Energy in Calories.

\section{Totals.}

Class 1. Class 2.

Under 3000

Over 3000

Nil

Under 100

Over 100

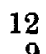

9
43
88
Percentages.

Class 1. Class 2.

$57.1 \quad 32.8$

$42.9 \quad 67 \cdot 2$

\section{Animal Food Energy in Calories.}

It will be seen from this that the lower paid tend to eat less at times than the higher paid and more at others, but the overlap in the two classes is considerable so far as total energy is concerned. In the case of animal energy, it will be noted that 16.0 per cent. of the lower paid eat no animal food whatever, and that 95.2 per cent. of the higher paid eat over 100 calories of animal energy as compared with 23.0 per cent. among the lower paid. It must, of course, be remembered from McCay's work that the higher paid, though they eat less total calories per day, probably absorb a much greater percentage of these than the lower paid. Besides, owing to their sedentary lives, their energy requirements are not so high. Even assuming that the energy value of the dietary of the 
well-to-do class is low, it has been shown by Noël Paton and Watson that the energy value plays only a subsidiary part in the production of rickets.

Protein. Among the lower paid, an average of $106.2 \mathrm{grm}$. of protein was consumed per adult per day, and of this 9.2 grm., or 8.6 per cent., were of animal origin. The better paid consumed $89.7 \mathrm{grm}$., of which $27.1 \mathrm{grm}$, or 30.2 per cent., were derived from animal sources. The distribution was as follows :

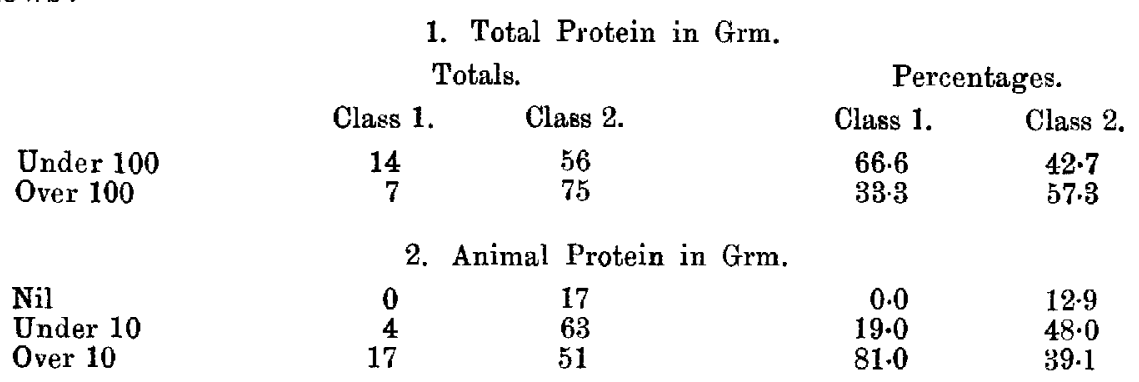

Here, again, we have a considerable overlap in the total protein consumed, though the lower paid tend to eat more. With regard to animal protein, 12.9 per cent. of the lower paid eat none whatever, while 39.1 per cent. eat over $10 \mathrm{grm}$. Of the better paid, 81.0 per cent. eat over $10 \mathrm{grm}$.

Fat. The average amount of fat consumed by the better paid was $59.5 \mathrm{grm}$. as against 44.3 by the lower paid. In the former animal fat amounted to 34.4 grm., or 57.8 per cent., while in the latter it was 3.0 grm., or 6.7 per cent. This brings into prominence the much smaller consumption among the lower paid of fat-soluble vitamin.

The distribution was ns follows :

1. Total Fat in Grm.

Totals.

Class $1 . \quad$ Class 2.

Under 40
Over 40

19

66

\begin{tabular}{cc}
\multicolumn{2}{c}{ Percentages. } \\
Class 1. & Class 2. \\
9.6 & 49.9 \\
90.4 & 50.1
\end{tabular}

Nil
Under 10
Over 10

2. Animal Fat in Grm.

0
2
19

16
104
11

$\begin{array}{rr}0.0 & 12 \cdot 2 \\ 9 \cdot 6 & 79 \cdot 3 \\ 90 \cdot 4 & 8.5\end{array}$

Here the overlap is not so marked as in the case of protein. The higher paid tend to eat a larger amount of total fat, and in the case of animal fat the difference is most striking, for while 12.2 per cent. of the lower paid eat none whatever, and only 8.5 per cent. eat over 10 grm., 90.4 per cent. of the higher paid eat over $10 \mathrm{grm}$. per diem. In this inquiry it was found that 1.5 per cent. of the lower paid ate over $20 \mathrm{grm}$. of animal fat, while 76.1 per cent. of the higher paid ate over the same amount.

Carbohydrate. The lower-paid worker eats a distinctly larger amount of carbohydrate than the higher paid. On an average, the former consumed $688.0 \mathrm{grm}$, as against 499.0 by the higher paid. Out of these $688.0 \mathrm{grm}$., 
1 grm., or 0.1 per cent., was of animal origin, while of the $499 \cdot 0 \mathrm{grm}$. consumed by the higher paid, $10 \mathrm{grm}$., or 2.0 per cent., were from animal sources.

The distribution was as follows :

\begin{tabular}{lcccc} 
& \multicolumn{2}{c}{ 1. Total Carbohydrate in Grm. } \\
& \multicolumn{3}{c}{ Totals. } & \multicolumn{2}{c}{ Percentages. } \\
& Class 1. & Class 2. & Class 1. & Class 2. \\
Under 500 & 12 & 22 & 57.1 & 16.7 \\
Over 500 & 9 & 109 & 42.9 & 83.3 \\
& 2. & Animal Carbohydrate in Grm. & & \\
Nil & 0 & 82 & 0.0 & 62.6 \\
Under 10 & 11 & 48 & $52 \cdot 3$ & 36.6 \\
Over 10 & 10 & 1 & 47.7 & 0.8
\end{tabular}

The difference between the two classes is seen from the fact that, while 47.7 per: cent. of the higher paid consume over 10 grm. of animal carbohydrate, only 0.8 per cent. of the lower paid consume over a similar amount.

\section{Commodities in the Diet.}

The articles of food consumed by all classes of Indians are very similar, and the following table will show how the consumption of these articles varies in the lower and higher paid classes. In European countries such striking differences do not occur.

TABLE III. Showing the Consumption per Adult per Day of the Various Foodstuffs among the Lower and Higher Paid Workers in the Town of Nasik.

\begin{tabular}{|c|c|c|}
\hline Article. & $\begin{array}{c}\text { Lower Paid. } \\
\text { Grm. }\end{array}$ & $\begin{array}{c}\text { Higher Paid. } \\
\text { Grm. }\end{array}$ \\
\hline Milk & $23 \cdot 3$ & $213 \cdot 3$ \\
\hline Ghee & 1.6 & 23.1 \\
\hline Mutton & 11.7 & 60.5 \\
\hline Dry fish & 5.5 & 1.5 \\
\hline Eggs & & $4 \cdot 0$ \\
\hline Bajri & $603 \cdot 1$ & 122.9 \\
\hline Rice & $201 \cdot 1-877.7$ & $250.6 \quad 533.9$ \\
\hline Wheat & $73.5)^{\circ}$ & 160.45 \\
\hline Pulses & 49.3 & 52.1 \\
\hline Oil & 11.8 & 15.0 \\
\hline Sugar & 17.4 & 58.8 \\
\hline Vegetables & 92.6 & 129.5 \\
\hline
\end{tabular}

In Miss Ferguson's Glasgow inquiry, it is stated that ' while milk was used by all the families, the average allowance "per man" per day was 256 c.c. in the rachitic and 309 c.c. in the healthier families'; and thus 'there is an appreciable difference in the amount of milk consumed by the two groups'. The quantities of the various food-stuffs consumed by the rachitic and non-rachitic groups are very similar, and in the critical Introduction of the M. R. C. to the above Report it is stated that ' in rickety and non-rickety families respectively, though there seems at first sight to be no significant difference, yet on examination it will be noticed that the rickety families do appear to consume more of 
those articles of diet which allow rickets to develop and less of those substances preventing rickets; for instance, they are found to eat more flour, potatoes, sugar, and oatmeal, and less milk, meat, butter, fish, eggs, and cheese. It is true that the figures given are not widely different, but it would be hard to deny that the difference might be sufficient to upset a poised balance.'

In the above table we have figures which are widely different, and on the above view the lower-paid worker eats a dietary which should produce rickets. When the consumption of milk and ghee in the Indian community is analysed, very instructive figures are obtained. The higher-paid workers consumed 213.3 grm. of milk per 'adult' per day, while the lower paid consumed 23.3. The higher paid consumed on an average $23.1 \mathrm{grm}$. of ghee, the lower paid consumed 1.6. The distribution of these substances among the various families gives equally illuminating results, for while all the higher paid took milk daily, 62.6 per cent. of the lower paid took none at all. Regarding ghee, 14.2 per cent. of the higher paid consumed none as against 78.6 per cent. of the lower paid. The distribution was as follows:

1. Milk in Grm. Totals.

$$
\text { Class 1. Class } 2 \text {. }
$$

Nil
Under 00
Over 50

Nil 10

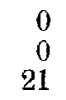

0
21

\section{(1)}

3

82
25
24

2. Ghee in Grm.

$\begin{array}{rrr}103 & 14.2 & 78.6 \\ 17 & 4.7 & 12.9 \\ 11 & 81.1 & 8.5\end{array}$

Percentages.

$\begin{array}{rc}\text { Class 1. } & \text { Class } 2 . \\ 0.0 & 62 \cdot 6 \\ 0.0 & \mathbf{1 9 \cdot 0} \\ \mathbf{1 0 0 . 0} & \mathbf{1 8 . 4}\end{array}$

$8 \cdot 4$

The number of the higher paid who do not eat ghee is due to the fact that they take extra milk and make their own ghee from this. The above figures become more instructive when it is mentioned that 47.7 per cent. of the higher paid eat over 200 grm. of milk per day and only 2 per cent. of the lower paid, and also that 52 per cent. of the higher paid eat over 20 grm. of ghee as against 1 per cent. of the lower paid. It has been found that 36 per cent. of the well-to-do families keep their own cow or buffalo.

The dietaries of seven rachitic families-three well-to-do Hindu and four well-to-do Mahomedan-were examiued in order to show that the dietaries of rachitic families were in no way inferior to the average of the class as a whole. The results are shown in Table IV.

It is clear from this table that the dietary amongst those families where rickets is found is quite as good as the average of the class as a whole, and that rachitic families consume as much milk and ghee as do the others of their class. 
Table IV. Dietaries of Rachitic Families.

Caloric value of dietary
\% fat calories in total calories
Vegetables per day in oz.
Milk in grm. per day
Ghee in grm. per day
Animal protein
" fat
Vegetable protein
, fat
" carbohydrate

1. Hindu.

\begin{tabular}{rrr}
1 & 2 & \multicolumn{1}{c}{3} \\
2741 & 2667 & 3000 \\
20.8 & $19 \cdot 6$ & 24.3 \\
6.4 & $5 \cdot 3$ & $6 \cdot 9$ \\
138 & 288 & 201 \\
11 & 11.5 & $12 \cdot 0$ \\
5.7 & $12 \cdot 6$ & $8 \cdot 4$ \\
16.1 & 22.2 & 22.5 \\
6.2 & 14.0 & $9 \cdot 4$ \\
59.0 & 51.9 & 65.4 \\
45.2 & 34.1 & 56.1 \\
456.3 & 444.3 & 470.3
\end{tabular}

2. Mahomedan.

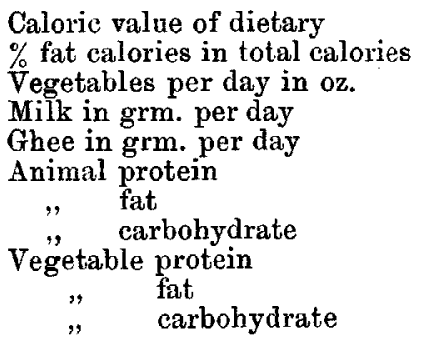

\begin{tabular}{|c|c|c|c|c|}
\hline 1 & 2 & 3 & 4 & $\begin{array}{l}\text { Average for } \\
\text { both classes. }\end{array}$ \\
\hline 3612 & 3666 & 2859 & 3409 & 3136 \\
\hline 17.1 & $23 \cdot 0$ & 24.8 & 20.9 & 21.5 \\
\hline 4.5 & 2.5 & $6 \cdot 4$ & 5.1 & 5.3 \\
\hline 214 & 266 & 115 & 195 & 202 \\
\hline $42 \cdot 9$ & $49 \cdot 8$ & 48.0 & 41.5 & 30.9 \\
\hline $30 \cdot 4$ & $33 \cdot 1$ & 21.8 & 23.5 & 19.3 \\
\hline 52.0 & $60 \cdot 7$ & $53 \cdot 1$ & $49 \cdot 6$ & 39.4 \\
\hline 9.6 & 11.7 & $5 \cdot \overline{1}$ & 8.7 & 9.2 \\
\hline 90.8 & $76 \cdot 6$ & 67.2 & 75.2 & $69 . \overline{4}$ \\
\hline 14.5 & 30.0 & $23 \cdot 3$ & $27 \cdot 1$ & $32 \cdot 9$ \\
\hline 599.4 & $567 \cdot 1$ & $430 \cdot 1$ & 550.3 & $502 \cdot 5$ \\
\hline
\end{tabular}

\section{Summary of Part I.}

In 1918 Noël Paton, Findlay, and Watson (6), in order to settle the aetiology of rickets, attempted a crucial experiment by keeping pups of two litters in the laboratory and feeding them on plenty of whole milk and porridge, and two pups from each of the litters in the country and feeding them on skim milk and oatmeal. The former developed rickets, while the latter did not do so. The remarkable point is that the artificial conditions arranged by these investigators are found naturally present in Nasik.

In the present inquiry, the general conditions of life in the two classes of the community are similar; but they differ on the point of dietary and social habits. The better dietary is used by Class 1 -the middle and well-to-do classes-but Class 2, with the poorer dietary, live an out-of-door life as contrasted with the indoor one of Class 1 , and have more fresh air, sunlight, and exercise.

The influence of the dietetic factor is considerably reduced, since all the children of both classes that I have examined are breast-fed, and this is prolonged to at least a year. In Class 1 the breast milk is supplemented when necessary with cow's milk; in Class 2 it is supplemented with rice and seldom with milk. Since the mothers of Class 1 eat a dietary containing more fatsoluble vitamin than those of Class 2, it would follow that the children of Class 1 get more fat-soluble vitamin than those of Class 2. 
Therefore, this natural Class 1-leading an indoor life and eating a good dietary-is exactly parallel to the pups which were kept in the laboratory and fed on whole milk and porridge, while Class 2-leading the open-air life and eating a poor dietary-corresponds to the pups kept in the country and fed on skim milk and oatmeal. Therefore, we should expect to find similar results as regards the incidence of rickets in the natural conditions in Nasik as were found in the experimental conditions artificially produced at home.

\section{Part II.}

\section{Early Rickets.}

I have already mentioned in the introduction that in the early stages of my inquiry I examined a large number of children in the smaller towns and larger villages of the district, and that, as a result of this investigation, I concluded that rickets was not a common condition. But later on $I$ found cases of rickets among the children of the well-to-do, and in order to determine its prevalence I carried out a house-to-house inquiry. During this I found a large number of bad cases of rickets which the parents had not considered it necessary to bring to the hospital for treatment. The importance of this fact is that it accounts for the belief that rickets is not a common disease in the Indian districts. In fact, severe cases are seldom seen, partly on this account and also because the normal high mortality among the children of all classes (which must be much exaggerated in the case of the rachitic ones) also helps to mask the condition. I firmly believe that evidence of severe cases of early rickets is seldom got in later childhood or in adult life because few of the children so affected survive childhood.

\section{Prevalence of Rickets.}

In considering the prevalence of rickets in the Nasik district, I propose first to take the cases in Nasik city as shown by the house-to-house inquiry, the hospital returns, and an examination of certain school children, and to compare these figures with those given by other parts of the distriet. I do so because Nasik conditions differ from those in the rural areas. Outside the city the life led is much more in the open air, and the purdah system, as understood in Nasik, is non-existent. At the same time the purdah-keeping Brahmin and Mahomedan communities are mostly to be found in the city, while, with one exception, there are few such families in the other parts.

I saw 224 families in the house-to-house investigation. These have been grouped into: (1) Class 1, which includes the well-to-do Brahmins, high-easte Hindus, and Mahomedans; and (2) Class 2, consisting of the poor, both Hindus and Mahomedans. I had intended to make three groups-(1) well- 
to-do Hindus, (2) Mahomedans, and (3) poor Hindus-but as the number of Mahomedan families is admittedly small, I think the above grouping is better. The poor Mahomedan's diet is similar to that of the poor Hindu, but differs from that of the rich Mahomedan, while he resembles the latter in keeping a modified form of purdah.

All the families in Class 1 consume milk and ghee daily, as has been seen already from the diet inquiry; 36 per cent. of them keep a cow or buffalo, and 46 per cent. own the house they live in. The average income was approximately four times that of the families in Class 2, being about Rs. 100 per mensem. In Class 2 about a third of the families took milk, but the quantity per head was only one-tenth of that consumed per head in Class 1 . The lowercaste Hindus keep no purdah whatever, and the poor Mahomedans keep a modified form of it.

The results of the inquiry are shown in the following table :

Incidence of Rickets in Nasik Families.

\begin{tabular}{|c|c|c|c|c|c|c|c|c|}
\hline Class. & No. of & $\begin{array}{l}\text { No. of } \\
\text { Children }\end{array}$ & \multicolumn{2}{|c|}{ Active Rickets. } & \multicolumn{2}{|c|}{ Healed Rickets. } & \multicolumn{2}{|c|}{ Total Rickets. } \\
\hline $\begin{array}{l}\text { Class } 1 \text { Well-to-do } \\
\text { Wello }\end{array}$ & & & Total. & $\%$ & Total. & $\%$ & Total. & $\%$ \\
\hline $\begin{array}{l}\text { Hindu } \\
\text { Mahomedan }\end{array}$ & $\begin{array}{l}85 \\
15\end{array}$ & $\begin{array}{r}277 \\
49\end{array}$ & $\begin{array}{r}38 \\
5\end{array}$ & $\begin{array}{l}13.7 \\
10 \cdot 2\end{array}$ & $\begin{array}{r}68 \\
9\end{array}$ & $\begin{array}{l}24.5 \\
18.3\end{array}$ & $\begin{array}{r}106 \\
14\end{array}$ & $\begin{array}{l}38 \cdot 2 \\
28.5\end{array}$ \\
\hline $\begin{array}{l}\text { lass 2- } \\
\text { Poorer }\end{array}$ & & & & & & & & \\
\hline $\begin{array}{l}\text { Mahomedan } \\
\text { Hindu }\end{array}$ & $\begin{array}{r}24 \\
100\end{array}$ & $\begin{array}{r}73 \\
260\end{array}$ & $\begin{array}{l}2 \\
1\end{array}$ & $\begin{array}{l}2.7 \\
0.5\end{array}$ & $\begin{array}{l}16 \\
16\end{array}$ & $\begin{array}{r}21.9 \\
6.1\end{array}$ & $\begin{array}{l}18 \\
17\end{array}$ & $\begin{array}{c}24 \cdot 6^{*} \\
6.4\end{array}$ \\
\hline
\end{tabular}

* The larger proportion of rickets in the poorer Mahomedans is probably to be accounted for by the partial purdah which they practise, their diet being practically the same as that of the poorer Hindus.

The difference between the two classes is very striking. The well-to-do Hindus give 38.2 per cent. of cases, while the lower-caste Hindus give only 6.4. Again, among the well-to-do, 13.7 per cent. were cases of active rickets, while the figure for the poor is only $0 \cdot 3$ per cent. I saw no severe eases of rickets in this class.

Turning now to hospital cases, I saw $\mathbf{5 9 0}$ children in the dispensary. Of these, 89 showed either active or healed rickets. The distribution among the classes and castes was as follows:

$\begin{array}{lccc} & \begin{array}{c}\text { Children } \\ \text { seen. }\end{array} & \begin{array}{c}\text { Cases of } \\ \text { Rickets. }\end{array} & \text { Frequency. } \\ \text { Hindus-well-to-do } & 103 & 40 & 38.8 \\ \text { Mahomedans-all classes } & 97 & 30 & 30.9 \\ \text { Hindus-poor } & 390 & 19 & 4.8\end{array}$

Here again we find the same distribution of the disease among the betterclass Hindu and Mahomedan children. Lastly, I examined the boys in one of the municipal schools, ranging in age from 4 to 10 . The great majority were Brahmins, Thakurs, and Kasars, who form the well-to-do and better educated 
class. The untouchable Hindus are excluded from these schools. Three hundred and forty-three boys were seen, and of these 35 showed genu valgum and 1 a deformed chest, a total of 36 or $10 \cdot 4$ per cent.

In one place only in the Nasik district did the results approximate to those in Nasik, and that was in Sinnar, about 18 miles away. Here there is a large Brahmin population. Two hundred and twenty children were seen, with the following results :

$\begin{array}{lccc} & \text { Children } & \text { Cases of } & \% \\ \text { seen. } & \text { Rickets. } & \text { Frequency. } \\ \text { Brahmins } & 181 & 25 & 19 \cdot 0 \\ \text { Other Hindus } & 89 & 6 & 6.7\end{array}$

These results may advantageously be compared with those obtained in other places where the Brahmin population was practically negligible and where no purdah was maintained.

$\begin{array}{lccc} & \text { Children } & \text { Cases of } & \% \\ \text { Seen. } & \text { Rickets. } & \text { Frequency. } \\ \text { Chandor-a decayed old town } & 100 & 6 & 6.0 \\ \text { Peint-jungle village } & 60 & 1 & 1.6 \\ \text { Malegaon-industrial town } & 653 & 31 & 4 \cdot 7 \\ \text { Yeola-trading town } & 581 & 29 & 4.9 \\ \text { Bandardhara-construction camp } & 172 & 4 & 2 \cdot 5\end{array}$

Taking the district as a whole, we find that out of 1,073 children, whose parents are well-to-do and whose mothers observed purdah, there were 268 cases of active or healed rickets, i. e. 24.9 per cent, while among 2,305 children of lower-caste Hindus there were 113 cases, i. e. 4.8 per cent.

In this inquiry certain interesting facts came to light, and it is necessary to consider these briefly, since I am of opinion that there is evidence to show that the prevailing complaint among the poorer classes is scorbutic in character. The following remarks are based on the examination of 1,947 children from birth to 12 years of age. 'The majority of these were the children of agricuiturists, artisans, and labourers, and included practically all the lower castes of Hindus found in the district.

The two most striking signs met with were pyorrhoea and beading of the ribs. Carious teeth were very uncommon, and in no case did I find the mouthful of carious teeth so often seen at home. Pyorrhoea occurred with great frequency, being found in its various stages in 71.5 per cent. of the children. It begins to appear almost with the eruption of the milk teeth, and at the age of 10 the gums usually showed distinct pyorrhoea and bleeding of the gums readily occurred on pressure. In 90 adults whom I examined, pyorrhoea was present in 72, or 80 per cent., yet carious teeth were uncommon.

Beading of the ribs occurred in 68.7 per cent. of the children seen, and this at all ages up to adult life. On account of its frequency, it was never used as a diagnostic sign of rickets. The beading was not- as a rule marked, but was clearly visible as a distinct rosary if the subject was made to bend backwards and so stretch the skin of the chest. I have seen the beading in adults. The worst cases I have seen were in those atrophic children so often found in the 
lower classes of Indians. In these there were no signe of rickets. I am of opinion that this sign is probably scorbutic in nature, for the following reasons: (1) Its occurrence at all ages of childhood. (2) The rarity with which rachitic changes accompany beading, and especially in those atrophic children where beading is most marked. (3) The presence of swollen gums, which bleed easily, and the wide prevalence of pyorrhoea in all classes and at all ages. (4) The low consumption of vegetables among all classes. This, we have seen, averaged about $4 \frac{1}{2}$ oz. per head. These signs are also common in the well-to-do classes in whom rickets is common.

Another sign requiring notice is the facial or Chvostek's phenomenon. This sign is associated with tetany, a disease closely related to rickets. The phenomenon occurs very frequently, and, curiously enough, I have not found it in children under four years of age. After that age, as will be seen from the following table, its incidence increases with age up to adult life. In old persons its frequency diminishes.

$\begin{array}{rccc}\text { Age. } & \text { Children seen. } & \text { F.P. positive. } & \% \text { positive. } \\ 1 & 40 & 0 & 0.0 \\ 2 & 46 & 0 & 0.0 \\ 3 & 32 & 0 & 0.0 \\ 4 & 50 & 0 & 0.0 \\ 5 & 85 & 12 & 14.1 \\ 6 & 148 & 33 & 22.2 \\ 7 & 204 & 72 & 35 \cdot 2 \\ 8 & 210 & 83 & 39.5 \\ 9 & 164 & 77 & 46.9 \\ 10 & 176 & 88 & 50.0 \\ 11 & 129 & 63 & 48.8 \\ 12 & 59 & 32 & 54.2 \\ \text { Adults } & 90 & 53 & 58.8\end{array}$

The significance of this occurrence with increase in age $I$ have not yet been able to determine, though it is possibly associated with gastric dilatation. I have very frequently come across cases, in adults especially, in which there is enlargement of the liver with tenderness and with constipation, dyspepsia, and dilatation of the stomach. It is also of interest to note that no cases occur below the age of four, when breast-feeding is almost universal. I have no means of testing the electrical excitability in these cases, but I am endeavouring to isolate methyl guanidin from the urine. I may, however, mention that I have met with several cases of adult tetany which showed typical carpopedal spasm and Trousseau's sign. For the present, it is important to note that this phenomenon is not found at the ages when active rickets occurs, and it is therefore very probable that it bears no relationship to this disease so far as Nasik is concerned.

To sum up, I may state that in the Nasik district rickets is a common complaint among the well-to-do Hindus and among Mahomedans, while among the poorer Hindus of the lower castes the disease is comparatively rare. Among all classes, the frequency of pyorrhoea with beading of the ribs suggests that a scorbutic condition is widely prevalent. 


\section{Clinical Notes.}

It is not my intention to describe in detail the clinical signs of rickets in this district, as the photographs (Plate 6) taken will show that these do not differ from rickets at home so far as bony changes are concerned. There are, however, certain minor differences which I have observed. In Nasik the anterior fontanelle appears to close more quickly than in England. The widely patent fontanelle was not observed so frequently.

Epiphyseal enlargement was the most common sign of the disease in its active stage; it nearly always was well marked and usually affected the wrists only. I never saw a severe case of active rickets in a poor child, and in this class epiphyseal enlargement was almost completely absent. When present, it was very slight. If this enlargement were scorbutic, the reverse incidence should have been found, since the very poorest seldom ate any green vegetables at all.

As has been mentioned above, beading of the ribs was never used as a diagnostic point of rickets owing to the frequency with which it was met. In rachitic children it was just as prominent a sign as at home. The posterior rosary was observed several times in bad cases.

The teeth, evon in the most marked rachitic cases, were nearly always in excellent condition. I have mentioned already that in all classes of the population the teeth were in good condition, but that pyorrhoea was very prevalent. In only six cases have I noted that there was a large number of carious teeth.

One point which $I$ would like to mention bere is that the infants of the poorer classes are far superior in physique to those of the better classes. Both are breast-fed, and the poorer mothers, though they do not get anything like the dietary of the more well-to-do women, are obviously harder and of better colour. This observation agrees with those of Noël Paton, Findlay, and Watson, who found that the 'country pups' on poorer food thrived much better than the wellfed laboratory animals.

\section{Discussion and Conclusions regarding the Aetiology of Rickets.}

The object of this investigation was to test the two opposed hypotheses as to the predisposing cause of rickets. It is held by one school that rickets is the result of a deficiency of fat-soluble vitamin in the dietary, and by another school that it is due to insufficient air, light, and exercise.

It has been found that in Nasik the population is made up of two strata: (1) Class 1, an upper stratum composed of well-to-do Hindus, chiefly Brahmins, and Mahomedans; this stratum forms the educated and moneyed class; and (2) Class 2, a lower stratum of artisans, agriculturists, and labourers who are uneducated and poor.

When these two classes are compared, it is found that in many ways they 
resemble one another. The general conditions of life, such as climate, clothing, sanitation, early marriages, \&c., are the same in both, and such special factors as pregnancies, miscarriages, and still-births are very similar. In fact, the two classes resemble one another in every way except in personal habits and in diet. Here the two classes are strongly contrasted.

The individuals of Class 1 lead a sedentary life, and they are rigidly bound by customs which are particularly binding on the women. The Mahomedan women of Class 1 are all strictly purdah, while in Class 2 a modified purdah is carried out. Anong the better-class Hindus, purdah is also maintained by the women. The effect of this on the children has already been pointed out, and as a result they also are confined to the house till they are able to walk and look after themselves.

The houses of these people are unhygienic to a degree. Stuffiness, as generally understood in England, is not found, but the rooms are extremely dark and the air is often hot. The women and children inhabit such dark rooms all day, and when a woman is confined she is shut up in almost complete darkness for a period of three months in the case of Hindus, and of forty days in the case of Mahomedans. Even after this the child is kept almost continually in a dark house.

When we come to examine the personal habits of Class 2, we find that the artisans and labourers from necessity lead a very active life and a more open one. There are no rules as to purdah, and no custom of semi-purdah for the women, who have to work as well as the men. The children are necessarily kept with their mother's all day, and so they spend all their time during the day in the open. The houses are usually ill-built and far from air-tight.

Turning now to the diet, we again find conditions widely divergent. The diet of both classes has been adversely affected by world prices, a local failure of crops in 1920-1, and high local prices owing to this being the year of a very big pilgrimage to Nasik. The general tendency has been to eliminate as far as possible the higher priced items, such as milk, ghee, vegetables, and meat, and to rely on the cheaper and more filling cereals. In Class 1 the result has been a smaller expenditure on such articles, in Class 2 their practical exclusion from the diet.

All Brahmins (the bulk of Class 1) are vegetarians, but take animal fat in the form of milk and ghee (clarified butter). The average consumption found by experiment was 34.4 grm. of animal fat per day per adult. All families took milk, and 36 per cent. had their own cow or buffalo. When necessary, breast-feeding was supplemented with cow's milk.

The remaining members of this class use a similar diet: but some castes eat mutton, and Mahomedans also eat beef.

In Class 2 mutton may generally be eaten, or in the case of Mahomedans, beef: but neither is procurable on an income under Rs. 30 per mensem. The staple food consists of unleavened millet cakes helped down with condiments and a small quantity of vegetables. The average animal fat consumption was $3 \cdot 0 \mathrm{grm}$. 
per adult per day. No cows or buffaloes were kept, and when necessary to supplement breast-feeding rice was given. In 62.6 per cent. of the families milk was not consumed at all and in 78.6 per cent. no ghee was eaten.

The dietaries of the two classes differ on the following points: (1) The caloric value of the dietary in Class 2 is greater than in Class 1. (2) The total fat in Class 1 is greater than in Class 2, the animal fat consumed averaging $34.4 \mathrm{grm}$. per adult in Class 1 as against $3.0 \mathrm{grm}$. only per adult in Class 2. (3) Class 1 consumes on an average 7.65 ounces of milk per adult per day, and 0.84 ounces of ghee; while Class 2 only uses an average amount of 1.01 ounces of milk and 0.05 ounce of ghee. (4) All families in Class 1 use milk; 62.6 per cent. of families in Class 2 use none.

It follows from these statistics that, even though both classes may consume an insufficient quantity of fat-soluble vitamin, Class 1 obtains very much more than does Class 2.

To sum up, we have in Nasik two classes in the community who resemble one another in every way except as regards dietary and social habits. The better diet is used by Class 1, the middle and well-to-do classes; but Class 2, with the poorer dietary, live an out-of-door life as contrasted with the indoor one of Class 1, and have far more air, light, and exercise.

Turning to the incidence of rickets in these classes, we find that the disease is most common in the families of Brahmins and other well-to-do Hindus, all in Class 1 ; less so, but still marked, in the case of Mahomedans, who fall partly into Class 1 and partly into Class 2 ; and slightly in the cases of the 'other Hindus', who all fall into Class 2.

We can now consider the two prevailing bypotheses regarding rickets in the light of these investigations. If a deficiency of fat-soluble vitamin from the diet is the real cause of rickets it should show the four recognized marks of a cause, that is :

1. Rickets should follow where the dietary is deficient in fat-soluble vitamin such as occurs in Class 2 ; but this class shows the smallest incidence.

2. Rickets should follow immediately on the coming into operation of this cause-the coming of a famine in the district, such as that now prevailing-and should affect those most affected by the famine. At the Bandardhara construction dam I examined 172 children, most of whom were the children of agriculturists from famine areas, and $I$ found only four slight cases of genu valgum. Many of the children were under a year old. Though the dietary of the parents was in most cases destitute of animal food, these infants were plump and well nourished.

3. The incidence should not be affected by other causes, such as sedentary or active habits of life; but rickets is common in the sedentary class and rare in the active one.

4. Rickets should affect those who eat a poor diet, but it does not.

These considerations show that a deficiency of vitamin in the diet cannot be a whole or a principal cause for the prevalence of rickets, for none of the necessary attributes of a cause are present. 

result.

But testing the rival theory by the same logical canons we get a positive

1. Rickets does follow on a sedentary life and prevails largely in the classes which have adopted a 'purdah ' or similar system for their women and children.

2. It follows immediately on the coming into operation of such a cause, for it afficts those children who are confined to the house after birth and also those who on account of a supposed delicacy have been confined to the house more than their brothers and sisters.

3. Provided this element of seclusion indoors is present, the incidence is not affected by other conditions, such as a more generous diet, better clothing, \&c., among the well-to-do.

4. Results show that the incidence of rickets is very heavy where such conditions of an indoor life are found.

5. All cases of rickets so far treated, ten in number, have yielded to a course of fresh air and exercise, showing that removal of the cause removes the effect. All other factors remained constant and no medicine was given. In all cases improvement was very rapid.

The evidence which has been put forward in this paper strongly supports the views of Dr. Leonard Findlay regarding the aetiology of early rickets, which are already well known. The difficulties which this investigator had in establishing his hypothesis were undoubtedly due to the impossibility of obtaining suitable conditions in Glasgow for the purposes of inquiry. From a knowledge of Findlay's work, I was at once able to appreciate the importance of local conditions in Nasik, and hence my present paper must be looked upon as an extension of the work already done by Findlay in 1915 and subsequent years.

The facts therefore show that if the lack of fresh air, light, and exercise is taken to be the cause of rickets, it is found to result where such a cause exists. This test therefore gives a positive logical result.

\section{Late Rickets.}

Late rickets, or 'rachitis tarda', is a disease which is found as late as the twentieth year of life in individuals who were previously healthy and non-rachitic. Such a definition, therefore, does not include cases of relapsed rickets, though it is probable that the aetiology in both is the same. Findlay (1) states that primary cases of late rickets after the age of four are undoubtedly rare. He also states that 'symptomatically and anatomically this variety (late rickets) of the disease is not different from that occurring during infancy, except that, since the growth of the cranial bones is not so active at this period of life, changes in the skull are slight or absent. On account of the absence of a negative balance in the calcium metabolism in examples of late rickets, Schabad considers that it is aetiologically different from that variety occurring in infancy. Pain and difficulty in walking, epiphyseal enlargement, rosary, bending of bones, flaccidity of muscles are all present and may be extreme.' 
I have been able to collect seventeen cases in Nasik, and it has been possible to study them from the aetiological standpoint and from the point of view of treatment. Owing to the comparative rarity of such cases, I propose first of all to make a few elinical notes on some of them.

Case 27. Hindu Brahmin, female, aged 14. States that she was quite healthy up to the age of 12 , and that she had no deformities before her present jllness. Married at 12 , but not residing with her husband. Before that age, ran about like other children and went to school, but at 12 she was confined to the house and hardly ever went out. Shortly after this, she began to suffer from pain in the knee-joints and waist, and this was accompanied by a low fever (bone fever) which lasted some months. The condition got steadily worse, and when seen she had great difficulty in walking. The gait was waddling and genu varum was present. There was slight lordosis. Facial phenomenon marked. Slight but distinct beading of the ribs present and also epiphyseal enlargement of the wrists.

The dietary in this case has been good and contained $288.2 \mathrm{grm}$. of milk and $11 \cdot 5 \mathrm{grm}$. of ghee per day. The parents are high-caste Brahmins. X-ray photo showed typical late rickets.

Treatment very successful. Has lost all pain and can walk 2 or 3 miles without difficulty.

Case 293. Hindu Brahmin, female, $16 \frac{1}{2}$ years. Complains of difficulty of walking and pains in the left thigh and hip of two years' duration. Up till three years ago patient went about like other children, but at that time she got married and went to live with her husband. Since then, she has seldom left the house, especially during the past two years, owing to the presence of pain in her limbs.

She states that two years ago she got an attack of bone fever which lasted for six months. This fever was of a low type and was accompanied by pains in the waist and thighs. It was followed by an attack of dysentery which lasted three months. She then began to have difficulty in walking, and this condition has got progressively worse.

At present she walks with a waddling gait. Genu valgum is present and is distinct: it is definitely stated that this appeared after the commencement of the illness. Epiphyseal enlargement of the wrists is marked, and both wrist and ankle joints are tender on pressure. Beading of the ribs is present, and the costochondral junctions are very tender. Lordosis is also present, and there is tenderness on pressure over the pelvis and back. F.P. very marked. Patient very well nourished.

Menses appeared eighteen months ago. No children. Diet has always been good, and she eats plenty of ghee and milk. A cow is kept. Her house, like the one in the previous case, is in old Nasik and is very unhygienic.

$\mathrm{X}$-ray photo showed typical late rickets. Treatment very successful. Pains gone, and can now walk long distances.

Case 298. Hindu Brahmin, female, 13 years. Complains of pains' in the hips and knees while walking: duration, five months.

Married a year ago, but not yet living with her husband. Before marriage was going to school and running about like other children : at that time had no deformities of any kind. For the past year she has been practically always confined to the house. Her walking about is nothing to what it was a year ago.

Five months ago, she began to suffer from pain in both buttocks, and this spread down to the knees. She also had pain in the ankles on walking. No history of fever or diarrhoea.

At present marked epiphyseal enlargement of the wrists and ankles (see 
Plate) and slight genu valgum of the right knee. Patient is thin and spare. Distinct beading of the ribs, but no tenderness. F.P. marked, involving all the muscles of the face.

Milk and ghee consumed daily in the house. Her father is not very well off, but for the past year the patient has spent ber day in the father-in-law's house, where a buffalo is kept, and as a result she has had plenty of milk every day.

$\mathrm{X}$-ray photo shown (Plate 7). Treatment with fresh air very successful. No pain. Can walk long distances.

Case 299. Sister of above, 11 years. Inability to walk and deformity of the Jimbs of two years' duration.

Up to the age of 9 years was running about like other children and had no deformities whatever. Two years ago child began to have diffieulty in walking. No history of fever or diarrhoea. With difficulty in walking, had pains in the lumbar region. This was followed by swelling of the wrists and ankles and later by deformities of the tibiae. Same diet as in above case. She was not in purdah when the condition started two years ago, but since then she has not been out of the house.

At present, there is marked outward bending of the tibiae at the lower ends. Very distinct enlargement of the wrists and ankles. Pigeon chest. Beading of ribs present. F.P. positive. If patient lifted, severe carpopedal spasm appears. Trousseau's sign easily elicited. Cannot walk or extend legs.

Since open-air treatment six weeks ago, all signs of tetany have disappeared. She can now walk the length of the ward by herself.

Case 402. Hindu Marwari, female, 17 years. Difficulty in walking of $2 \frac{1}{2}$ months' duration. Married eleven months ago, and since then has been much more purdah than she ever was before. Up till $2 \frac{1}{2}$ months ago was quite healthy. She states that for the past five or six months she has had 'bone fever' accompanied by pain in the back. There were no bony deformities before the present illness. She has no children.

At present, genu valgum marked. Epiphyseal enlargement of the wrists slight. Beading and tenderness of the costochondral junctions. F.P. negative. Lordosis present. Has great difficulty in rising up if she has sat down for a few minutes, and when she has risen she cannot walk for two or three minutes. No treatment followed.

Case 17. Hindu Brahmin, female, 13 years. Difficulty in walking and pains on walking of one year's duration. Illness started a year ago with fever, which lasted four or five days. With this, diffieulty in walking started, and also pains in the pelvis and thighs, and these have remained the same till now.

Patient unmarried. Still attending school, but after she returned from school she stayed in the house all the time. At present, genu valgum distinct, and this has appeared in the past year. No epiphyseal enlargement. F.P. positive and very distinct. History of carpopedal spasm. Trousseau's sign present.

Patient well nourished and fat. Diet good, as patient belongs to a well-to-do family. Tetany appeared with fever a year ago and again during the second attack of fever which she had ten days ago. No treatment followed.

Case 88. Hindu Brahmin, female, 13 years. Complains of pains in the limbs and cough of four months' duration. Healthy up to four months ago, and at that time she began to have trouble in walking, and day by day since then the trouble has got worse. Now she cannot walk any distance.

Patient went to school till two years ago, and then she was confined to the house. The family is well off, and milk and ghee are consumed daily. For the past fifteen days has had fever in the evenings, but no pains. Beading present with tenderness of the costochondral junctions. Epiphyseal enlargement of 
the wrists with tenderness. No deformities. F.P. positive. Looks fairly well nourished. No treatment.

These clinical histories are typical of the majority of cases seen, and with regard to the seventeen eases which I have examined the following points require notice :

1. All the cases were found in females.

2. Sixteen cases were found in Brahmins and well-to-do Hindus and in Mahomedans, i. e. in those classes who keep purdah or semi-purdah and whose dietaries were good. One of the cases was found in a Tanner, a caste which does not usually keep purdah, but in this particular case it was admitted that the woman rarely left the house. One case only was found among lower-class women, though I saw many more of such women than I did of Brahmins.

3. In practically all the cases, it was definitely stated that milk and ghee were consumed daily, and frequently a cow was kept. The worst cases were found among poor Brabmins who had to keep semi-purdah, but whose diet was not as good as that of the well-to-do.

4. The mean age of incidence of the condition was 15.6 years. The maximum was 32 years and the minimum 9 years. The majority of cases began between 12 and 13 years.

5. The majority of cases showed deformities of the lower limbs, but it would appear that the later the onset the less likely are the limbs to be affected and the more likely the pelvis.

In late rickets, then, we have a condition resembling clinically early rickets, and which from the aetiological point of view presents the following features :

1. It occurs in the well-to-do and not in the poorer classes. The former we have seen obtain a much larger supply of fat-soluble vitamin.

2. It occurs where the purdah or semi-purdah life is adopted, i.e. in the Brahmin, well-to-do Hindu, and Mahomedan.

3. It occurs soon after the purdah life is adopted, and this change of life is not accompanied by any change in diet. It does not occur in the poorer classes or in men, who do not adopt the purdah life. As already stated, early rickets and late rickets both occur after the purdah life is adopted, i.e. in infancy and about the age of 12. In the former, both sexes are affected because both are confined to the house; in the latter; only females, because they only maintain purdah about the age of 12 .

4. Its occurrence is not affected by diet, i. e. if diet be a cause, the incidence of late rickets should not be affected by purdah, but it is. If purdah is a cause, it should not be affected by diet: and it is not, because we find the disease where the diet is best and do not find it where the diet is worst.

5. It does not occur in the poor who eat a diet poor in fat-soluble vitamin, but who take plenty of fresh air.

The same conclusion is therefore arrived at as in the case of early rickets, viz. late rickets is the result of the purdah and semi-purdah modes of life. This 
is confirmed by the result of treatment. Other things being equal, removal of the cause removes the effect. In six cases of late rickets treated on open-air lines, all the patients lost their pains very rapidly and were able to walk much longer distances than they could before. In no case was medicine prescribed, and the diet taken was brought from the patient's house, and was exactly what she had always been having.

\section{General Conclusions.}

From the inquiry in this district, I have seen many cases of rickets, both early and late. These conditions occur almost exclusively among well-to-do Hindus and Mabomedans. The purdah form of life leads to a lack of fresh air, sunlight, and exercise. The dietary of this class has been shown by investigation to be far superior to that of the poorer class in which these diseases are almost completely absent. The larger consumption of milk and ghee entails a greater supply of fat-soluble vitamin to the class which suffers most from these diseases. It has already been shown that by the logical canon of difference, a deficiency of fat-soluble vitamin cannot be the principal cause of rickets.

This investigation, then, bears out entirely the crucial experiment devised by Noël Paton, Findlay, and Watson. The natural conditions of life in Nasik are exactly parallel to the experimental conditions arranged by these observers, and from the incidence of rickets in Nasik exactly similar results have been obtained. The conclusion is therefore come to that the most important aetiological factor in the production of rickets is lack of fresh air, sunlight, and exercise.

I desire to thank Mr. S. J. Shah, my assistant in the hospital, for his invaluable help in obtaining cases. I would also thank Mr. A. Appleyard, M.Sc., and Mr. F. Hirst, A.R.C.S., of the Government Acetone Factory, for carrying out my chemical analyses and for much helpful criticism; Colonel T. S. Novis, I.M.S., of Bombay, for allowing me to have the X-ray photographs done in the J. J. Hospital in Bombay; and finally, Mr. S. J. Murphy, I.C.S., District Judge of Nasik, for his valuable assistance in arranging about my house-to-house inquiry, and in helping to overcome the prejudices of the people.

\section{REFERENCES.}

1. Findlay and Ferguson, 'A Study of Social and Economic Factors in the Causation of Rickets', Med. Res. Com. Spec. Rept. Ser., Lond., 1918, No. 20.

2. Greenfield, Joum. Assoc. of Medical Women in India, v. 13.

3. Noël Paton and Watson, Brit. Med. Journ., 1921, i. 594.

4. Breinl and Young, Trop. Dis. Bull., 1916.

5. MoCay, Scientific Memoirs, Govt. of India, Calcutta, 1910, New Ser., No. 37.

6. Noël Paton, Findlay, and Watson, Brit. Med. Journ., 1918, ii. 625. 


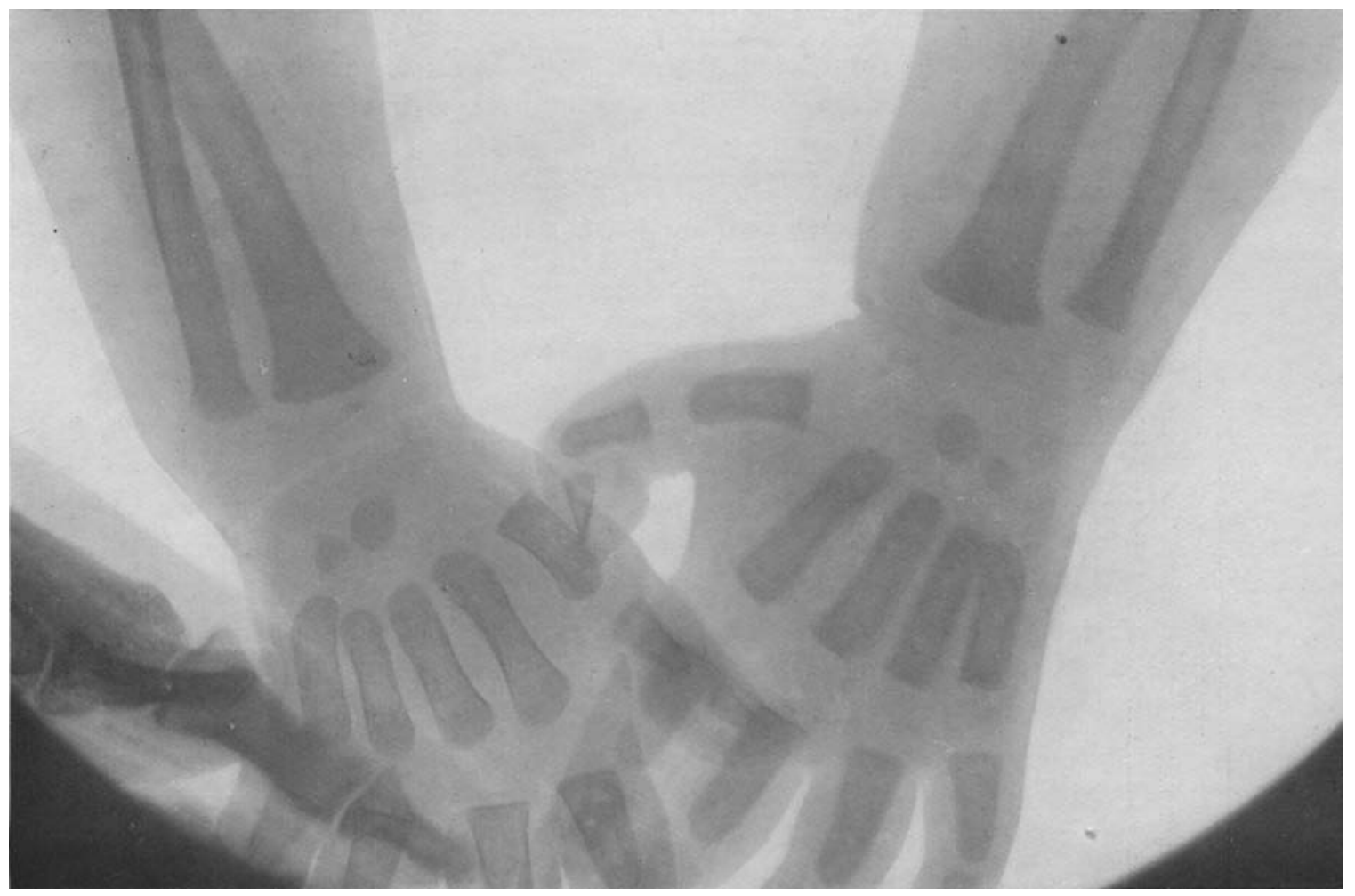

Normal Wrist

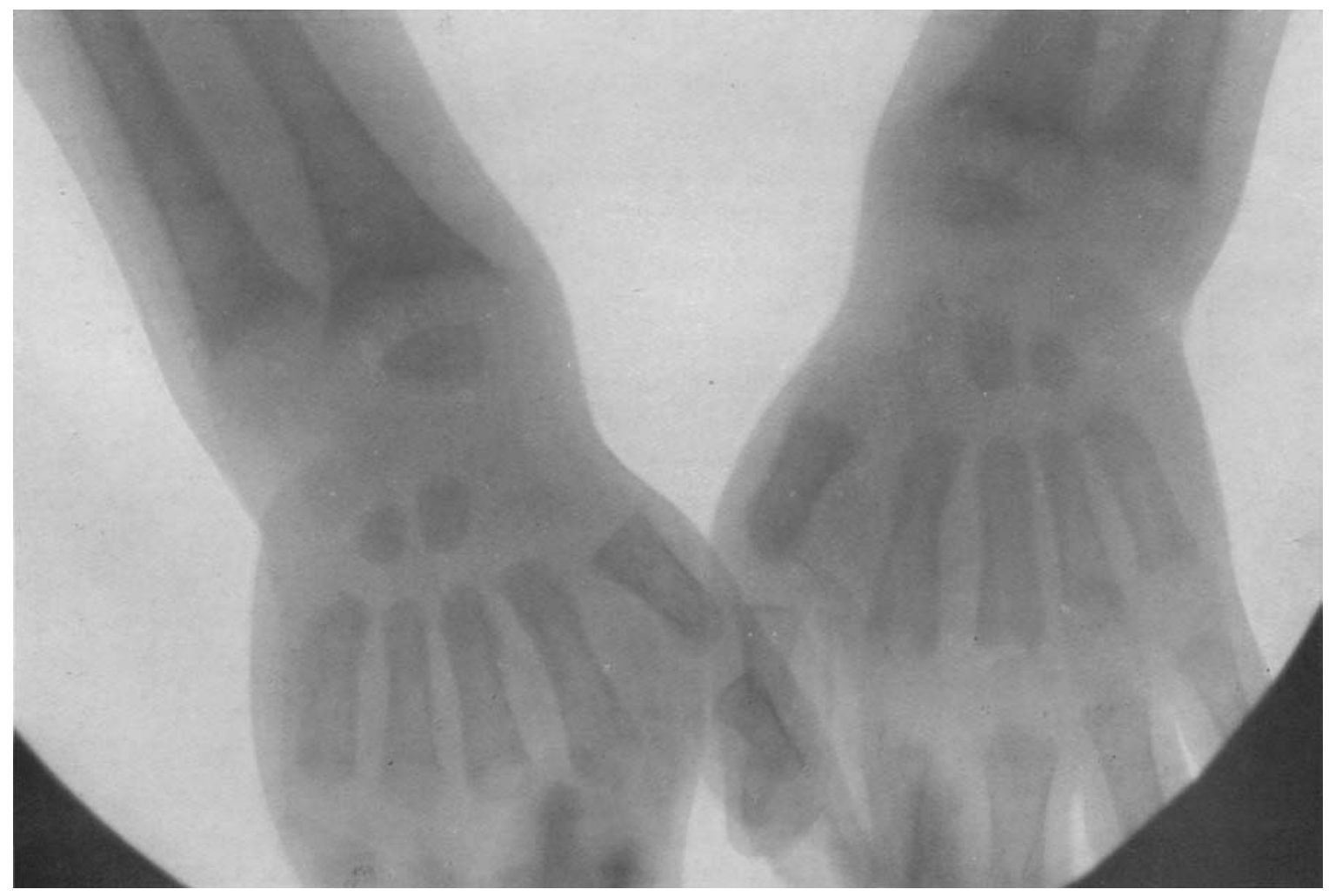

Rickets. Brahmin Child 


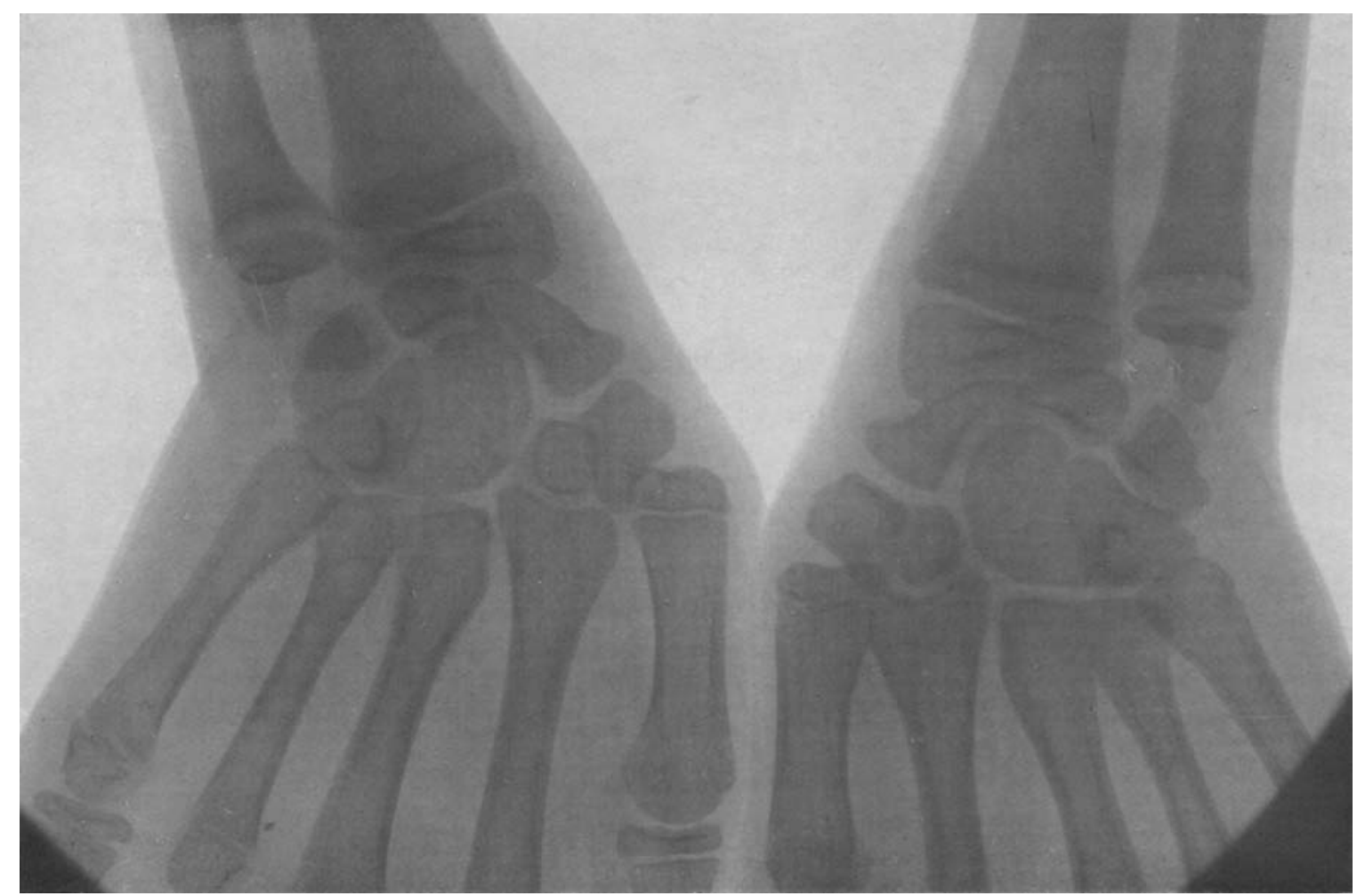

\section{Mahomedan}

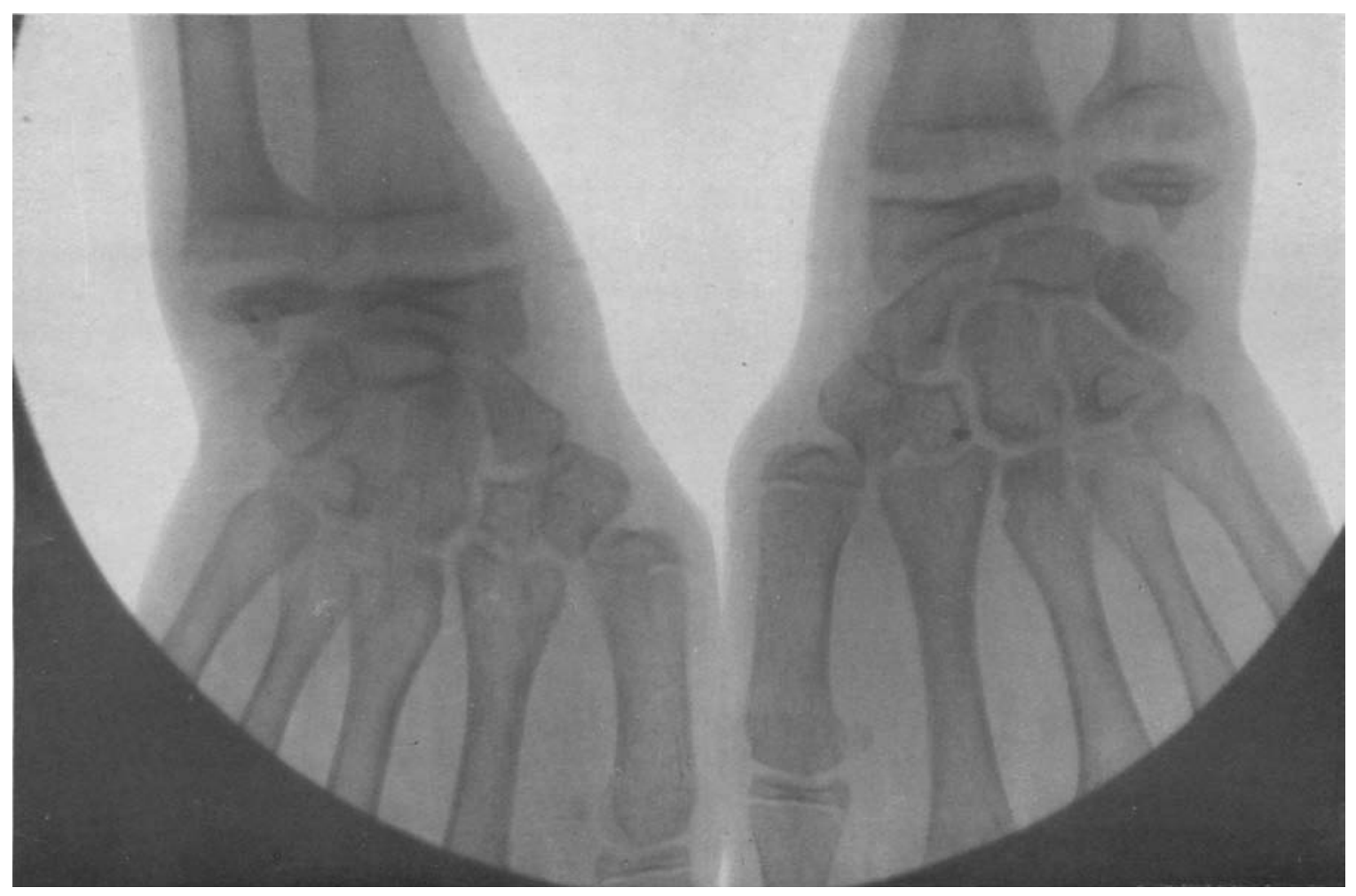

Brahmin. Case 298 